DOI https://doi.org/10.32841/2409-1154.2019.42.1.19

Babayeva M., $\mathrm{PhD}$,

Azerbaijan State Pedagogical University

\title{
ASHUG MOLLA JUMA'S LITERARY HERITAGE AND WAY OF LIFE
}

Summary. Ashug creativity is a national and spiritual wealth of the people, and it is a culture without analog. It has been at the forefront of our thinking, values, and identity for thousands of years. The suffering of the Middle Ages was passed by our people with these traditions of art. The mood that ashug creativity instilled in us is the ancestor of our greatgrandfathersn and it still holds the same sacred function today.

The article has analyzed the various aspects of the life and creativity of Molla Juma, one of the invaluable masters of Azerbaijani ashug art. Master's poems in various sources, poems in memory of folk artists, talkings about him have been gathered and commented on. A number of controversial points have been clarified, and a analysis of M. Juma's legacy has been scientific-theoretically analyzed. The ashug art is an integral part of our centuries-old history and culture. The pearl of art that brings our past to our present and present to our future is a great art that embodies the wishes and aspirations of the people. For this quality, ashugs are known among the people as "ashug of truth", "the voice of ashug is the voice of truth" and "ashug is the beauty of the people". One of them is Molla Juma, one of the most powerful representatives of the ashug literature, who lived and created in the late $19^{\text {th }}$ and early $20^{\text {th }}$ centuries. The beauty of man and nature, the inner world of man, the value given to the world, the moral values, religious and didactic themes were among the most frequently addressed poems. Molla Juma entered the history of the ashug literature as an innovative ashug poet. His renovations on the ashug poetry have been welcomed by both contemporary artists and subsequent masters. The main part of the poetic heritage of the great artist still preserves its activity in the ashug repertoire. For the first time, a prominent scholar Salman Mumtaz gave the information about Molla Juma and included his poems to the collection. The first example of Molla Juma's creations is found in Volume I of the book "Azerbaijani ashugs", published in 1929 by the renowned folklorist H. Alizadeh. Molla Juma's "deishme" with Ashug Konlu is about a hundred points, and there are many colorful themes. In these "deishme"s the personal, original thoughts of the ashugs about nature, society, the world are centered in issues on high talent, spiritual wealth, social, psychological, ethical, and upbringing.

Key words: music, poem, national, nation, creativity.

Introduction. The ancient roots of ashug poetry, which has penetrated deep into the Turkish world relate to oral folk literature and folk art, as well as artistic activity of the people. Its fragments are in "bayatis", folk parables, folk music, natural, indispensable, daily artistic activity of the people. Ashug's art has a long history. If it could create a monument of immortal art, such as "Dada Gorgud", its first roots should be deeper. Azerbaijani ashug poetry and ashug art began to emerge long before the emergence of the Dada Gorgud epics. In these epics, ashug plays a great role. He is described as a wise, intelligent man, and is called a "knowledgeable person". It is even shown that Dada Gorgud, who wrote the epics, is Ashug himself. Since ancient times, the people of Azerbaijan have been very fond of Ashugs and have always respected them. In this art, music, singing, dancing and poetry complement each other. Therefore, many-field ashug art is as difficult and complex, demanding excellence, sensitivity and skill as it is glorious. The ashug art is an integral part of our centuries-old history and culture. The pearl of art that brings our past to our present and present to our future is a great art that embodies the wishes and aspirations of the people. For this quality, ashugs are known among the people as "ashug of truth", "the voice of ashug is the voice of truth" and "ashug is the beauty of the people". One of them is Molla Juma, one of the most powerful representatives of the ashug literature, who lived and created in the late $19^{\text {th }}$ and early $20^{\text {th }}$ centuries.

Discussion: The most authentic source of Molla Juma's life is poetry and epics. He was born at the end of the nineteenth century (in 1854) in the village of Ashagi Laisgi in Nukha region. The pseudonym "Molla" was given to him because he was literate. Molla Jums's main occupation was agriculture. He harvested the fields of the rich people of Gakh, Zagatala, and Balakan, and took care of his family with this salary. Molla Juma received his first education at the Madrassah of Ibrahim Efendizadeh in the village of Ashagi Goinuk. For a short time, he has learned Arabic and Persian perfectly. Information on the picture of ashug was given by Mahyaddin Abbasov (Pashazade), a journalist who has headed the editorial office of the newspaper "Worker of Shaki" for the first time. In his autobiography, researchers wrote that his grandfather, Molla Oruj, was a poet. Molla Oruj's poem "Burslu gizi" is the only piece of art that has come to us.

Molla Juma fell in love with a 19-year-old girl. Ashug kept her name, and called her "Ismi Punhan", and glorified her in his poems until the end of his life. Some researchers believe that Molla Juma fell in love with a girl from a religious place but was forbidden to name her. According to some locals, Ismi Punhan was noted to him in his dream. She was daughter of Sheikh Nasrullah, a resident of the village of Shabalti in the Gakh region. Sheikh's house was a place of pilgrimage. That is why Molla kept her name. Some experts speculate that the "Ismi Punhan" is Molla Juma himself. Molla Juma also dedicated poetry to her when "Ismi Punhan" died. It is clear from poem that she passed away very early. Some of Ashug's poems state that "Ismi Punhan" stays away from ashug, and even left out of love, becomes estranged and generalized, thus becoming the ideal 
of life of ashug that he wants to achieve in life, but never could get. Some legends indicate that "Ismi Punhan" is the daughter of the owner of madrassa in which Molla Juma studied in his youth. From these narrations the idea is: Molla Juma could only hide the name of her lover if she would be the daughter of a madrassa teacher or the most religious person. We also think that in folklore, especially in the love lyrics of the people, the names of the beauties have never been anonymous. In the epics of love, the poor ashug, whose only richness is hope and the word art, falls in love to the daughter of the richest man of the time, describes her with her name. It means he does not hide her name. "Ismi Punhan" is undoubtedly a mystery about Molla Juma's biography, creativity and outlook.

Professor P. Afandiyev noted that Molla Juma expressed date of love to "Ismi Punhan" and that date was 1873 (at the age of 19). "Juma, who spent his childhood in Laiski, he goes to the village of Ashagi Goinuk to visit the mosque of Haji Ibrahim Efendi. His talent and endless passion for science make him lovely to his friends here and his murshid Ibrahim Efendi and his family. He becomes very close to this family as the family member". In 1873 (hijri 1290) a love adventure begins between Molla Juma and the daughter of Ibrahim Efendi, a lyrical hero who calls "Ismi Punhan" with great love and infinite respect in the poet's poems ... Ibrahim Efendi, who is aware of this incident, drives Juma out of the mosque. The young poet, whose heart beat with love, returns to his native village... In a poem Molla Juma says that, Ismi Punhan died of a plague in 1892. It should be noted that Pasha Afandiyev the consideration about Molla Juma's love to daughter of his murshud İbrahim Efendi and calling her Ismi Punhan is not based on any fact (13). Molla Juma was an active supporter of the Azerbaijan Democratic Republic (1918-1920). At that time, while in Karabakh and Zangazur, Armenian pirates punished the peaceful Azerbaijani population, as in other regions, volunteer groups were established in Shaki to assist the Azerbaijani army. One of those groups was created by Ashug Molla Juma and his cousins. In May 1920, all of his relatives were arrested in the repression by the Bolsheviks after the Sovietization of Azerbaijan.

Oral information about Molla Juma's death can be divided into three groups. According to the first option, during the arrival of the XI Golden Army to Azerbaijan, "Mollas" were collected and transported somewhere and killed secretly. The second option is that Molla Juma was among the villagers during the shooting, and, like many others, was shot. The latter, and most claim, is that the ashug was killed by Armenian soldiers when the XI Golden Army arrived. The great-grandson of Molla Juma, folklore historian Elman Azizov in the article "Last days of Molla Juma" published in the book Ismi Punhan, the most popular edition of Molla Juma's legacy, based on his grandmother's telling interesting and true information about the killing of Molla Juma, brings to our attention as following: "I (Molla Juma's daughter Reyhan) was 14 years old. The spring of that year (1920) came quickly. The mulberry in our lives has grown, and my mother cooks the mulberry, and I helped her. My father was busy with writing issues at home. Soon he came up to us and said to me: "Take it, my daughter, that they may remember me from you". He had a watch, a pocket knife and a purse. He gave them to me and went home. A surprised mother said: what does that mean?". My father turned around, took a look at me and then my mother and said: "Tomorrow at this time, you and I will not be in the world" (16). My mother almost turned numb, and I was looking at the gifts in my hand, and I didn't even know what my father was saying. The horsemen knocked on our door this morning. They spoke Azerbaijani. They say the new government is calling you to the printing house. My father rode his white horse and went with them. The wife of our neighbor, Kara Mammad, came with anxiety and said that her husband and sons also went with Molla Juma. The whole village was in trouble. Women and children gathered in the house of Kara Mammad. About half an hour after the departure of the horse, the gunfire was heard. Soon the soldiers began to enter the courtyard of the house where we were. Mother Zohra stood on the stairs and shouted: "Where do you enter? There are families here". One of the soldiers, who did not listen to my mother, began to raise her arms in her hands. My mother hit the soldier with an ax in her hand and threw him down the stairs. Seeing this, the soldier in the courtyard opened fire. My mother fell to the door with an ax in her hand. After this, other soldiers began to set fire to the house. One of the women inside the house opened the window and we jumped out of the window to the back of the house started to run away in the direction of the village of Bash Laisgi. We were hiding during the day, and we missed the nights not to get into the hands of the enemy. Two days later our relatives from Bash Laisgi found us in the woods" [6, p. 20-21]. According to Idris Mustafayev, a childhood friend of Molla Juma, Molla Juma's body was found in the late 1920s on the sidewalk. Mustafayev notes that Molla Juma's body had been hit by swords in several places, his face was unrecognizable, and he was only recognized by his clothes. Armenians from Sabatli village of Shaki play a role in his death. Academician Y. Mahmudov writes about this in an essay entitled "The Martyr of Independence Molla Juma": "My father used to speak every day events he witnessed: We are the youth of Goynuk demolished the Dashnak camp nesting in a favorable strategic location, Sabatli village, and preparing to drown Shaki in blood, in 1918. We drove the Armenians to the other side of Ganik. We went to Ganja to the meeting with Nuru Pasha and informed him about it. We rode till Bilajari on Nuru Pasha's proposal. We participated in the battles. But the Bolsheviks destroyed our independent government. "Troika" started "cleaning" in Sheki. One member of Troika was Armenian. And obviously they were taking revenge of Sabatli from people of Goynuk. Everybody they met on the road and "suspected" were shot dead. Molla Juma was also questioned while traveling with friends in the lower Goynuk with saz on his shoulders, after playin on the saz he was released with the instruction of a Russian member of Troika. However, after some distance, he was killed in the back fire by the conspiracy of an Armenian member of Troika. According to my father, it happened a month or a half after the Bolsheviks came to power" (17).

Molla Juma taught dozens of students the secrets of folk art. The following are the names of the students: "Lezgi Ashug Yarali, Muhammedali, Umid Aga Gozlu, Ashug Isgandar, Ashug Muhammed, Ashug Haji Muhammed from Putul (Dagistan), Ashug Ismay1l from Gadrukh (Dagistan), Molla Oruj from 
Zayam (Gakh), Ashug Yusuf from Lower Goynuk, Baş Layısqılı Ashug Hajibala from Bash Layisgi, Ashug Karamoglu, Ashug Muhammed Gachayoglu, Alizade Almalı, Kara Oruj from Ismaylll and others" [5, p. 596]. Molla Juma's poems are widely distributed both in oral and in manuscript form. Molla Juma traditionally wrote all his poems in one single paragraph. Ashug starts poems with "Divani". In all his manuscripts, the word "goshma" (form of an Azerbaijani poem) is not mentioned, it is called as "gafiye" (rhyme); "Dubeyti", "hejabeyt" was in the form of "garayli". Some of the manuscripts were copied and distributed by secretaries. And amateurs copied from manuscript owners and kept for themselves. Molla Juma's manuscript found in Shaki lists the names of his poems: "People, here in my book is written: firstly "divani" and secondly "gafiya", third "dubeyti", fourth "hejabeyt", fifth "kukari" and "arabi", sixth "tajnis", seventh "takhmis", eighth "shikasta", nineth "bayati", tenth "garaheja", eleventh "dodagdeymez", twelweth “mukhammas"”, $(4,21)$.

In the literary heritage of Molla Juma, "hajv"s play an important role. In many of his "hajv"s, the rich, a clergyman, a merchant or a landlord, have been severely criticized. selfishness, humiliation, oppression, hypocrisy, lies and greed of richest people such as Gipchakli Hajı Kerim, Cavad aga from Sheki, Akhsag Lachın, Almalı Isa, Said and others is said directly to their faces in the "hajv"s of the ashug. He complained of his life, sometimes called the rich and the strong to justice, goodness, generosity, defended the poor. Especially in recent poetry, he had high hopes for a fair, free, happy time. In the literary legacy of Molla Juma there are many poems about the ancient East, Azerbaijani legends and myths, especially the Islamic world. He does not preach Islam in any of his poems, nor does he calls people to religion, but expresses the greatness, holiness and inviolability of Islam in heartfelt words.

There is a strong hatred to the clergy in Molla Juma's creations. Many poems of ashug's "Molla", "Efendi", "Hajilar", "Olajag" and others are of particular interest in this regard. Ashyg confesses to all the deceptions of religious leaders who have lost their way through poems, and has made it clear that in a thousand different ways, they have taken away their possessions. In ashug's poems he speaks about human beauty with great sincerity. He had a delicate taste and instilled in the person's inner and mental feelings in beautiful, touching expressions. Molla Juma pronounced the names of the beauties praised in letters of pecuniary account, or adapted the letters of the beauty's name to the tone of the poem. In many of his poems, he expresses his longing for four letters. But these four letters are different letters in different poems.

One of the most praised by Molla Juma is a beautiful, warmhearted and hospitable lady called Nigar. When he came to Chobankol, Molla Juma was the guest of the family. Molla Juma remembers Nigar in several of her songs and finally dedicated her three poems. The first is a poem compiled of five paragraphs. Here, Nigar is described as the greatest, most sacred, and most beautiful of the nation. Every time when he traveled to Zagatala, Molla Juma visited this family. One day he comes to see Nigar, her mother Aishakhatun. Meanwhile, Aishakhatun sees through the window that Molla Juma opens the door and enters. She cannot restrain herself, beating her knees and throwing her hair in front of him. Molla Juma understands. He comforts Aishakhatun, and at this moment a second poem runs through the head of Molla Juma. "I saw you alone at Chobankol, Nigar," the ashug says elegy to the girl, who has just passed away.

There are many poems by Molla Juma on public issues. Some of these are directly related to the hard work and labor of the ashug. The poems "My wife" and "Sparrows" are among them. Many of Molla Juma's epics are known: "Molla Juma and Ashug Konlu", "Gafiya and tajnis", "Deishme between daughter and bride", "Molla Juma and Ashug Donu", "Molla Juma and dabbakh", "Sayyad and Sayali". "Molla Juma and Ashug Konul" is consisted of "goshma" and "deishme" of Konlu (The dastan was told by Molla Juma himself instead of both). Some of the "baglama"s in the dastan is reminiscent of "deishme" related to religious themes in Azerbaijani epics such as "Abbas and Gulgaz", "Valeh and Zarnigar" and others.

Molla Juma's "deishme" with Ashug Konlu is about a hundred points, and there are many colorful themes. In these "deishme's" the personal, original thoughts of the ashugs about nature, society, the world are centered in issues on high talent, spiritual wealth, social, psychological, ethical, and upbringing. It is characteristic of the addition of Islam-related "baglama" and "gifilbands" to such "deisme". Some say that ashug Konlu met with Mulla Juma for the first time in a tea house in the village of Upper Car in Zagatala. Molla Juma "closed" her in the tea house in front of people. This was repeated several times. One of Molla Juma's interesting and great "deishme" is called "gafiya and tajnis". Gafiya is what Molla Juma called instead of goshma. He never used the word goshma anywhere. The poem is 53 paragraphs.

The literary heritage of Molla Juma, who wrote his poems at different times, was only collected, printed and delivered to readers during the Soviet era. The Gakh manuscript, containing 92 pages, involves about 200 poems. In that manuscript the poems are arranged and numbered by the forms. The manuscript begins with "mukhammas". Then comes the "tajnis". There are many examples of "tajnis's" in the manuscript. One of them is called: "Tacnis dodaqdayməz, özü do yedəklama, alif əvval axır". At the end of the poem it is written: "Afarin o adama ki, bu tacnisi oxuyub manasin bila, bilmayan qanmaza heyfdir, heyf" $(8 ; 34)$.

There are also "bayati"s in Molla Juma's manuscripts. There is a special page dedicated to the "bayati"s, which are always written in white spaces on the edges of the sheets. "Bayati"s of ashug is in a number of different topics. Pure love is glorified in the "bayati"s. "Bayati"s are very exemplary, characteristic examples of folklore. Nightingale, flower, gazelle, lamb, Moon, Sun, star, black eyes, fortune, narcissus combined with great skill in the traditional ground of folk bayati. "bayati"s of Molla Juma is distinguished from public one. Public "bayati"s are started with "mən aşiq", "Aşiqəm", "Әzizim", "Eləmi" and so on. It is not the same with "bayati's" of Molla Juma. "Dubeyti" is also form of poems of Molla Juma. The poem is only 30 points. All points is written on "garayli". There is some legend about this poem: When Molla Juma run "majlis" in Bash Goynuk village of Shaki. Women also would come to such "majlis"s. They would sit in a separate room or in a corner of big room. It is said that 
Ismi Punhan also was among women. When "majlis" launches, Ismi Punhan wonders if Molla Juma still has ashug's ability. In her mind she remembers the names of the birds to check him. If Molla Juma would be real ashug, he will feel it. Molla Juma as real ashug feels what dreams Ismi Punhan and creates poem. Ismi Punhan already believes that Molla Juma is still real ashug. The names of birds are heard. This is the first time I've heard some of them. Pigeons, owls, crows, crabs, hawks, horns, turrets, pigeons, pheasants, pirates, shamaga, storks, ducks, jintals, bazdak, bustard, goose, nightmare, salmon, partridge, eagle-owl.

Molla Juma's creative legacy also covers "dastan"s writen by him. Although it is said that he has created about seven dastan, three of them are noteworthy in the ashug repertoire. The epics by Molla Juma, mainly in the repertoire of Sheki-Balakan and Derbent-Dagestan Ashugs, are in the form of traditional love epics. The traditional stages of love and success in the plot line of the epics "Sayyad and Sayali", "Bakhish bek and Leyla khanum" are at the level of classical epics standards. Molla Juma prepared the epicenter of these epics on the basis of a fairy tale, and placed poems and "deishme" on appropriate moments. The epic "Juma and Konul" is a collection of legends related to "deishme" between Molla Juma and Ashug Konul. It was created by students of the ashug. Molla Juma entered the history of the ashug literature as an innovative ashug poet. His renovations on the ashug poetry have been welcomed by both contemporary artists and subsequent masters. The main part of the poetic heritage of the great artist still preserves its activity in the ashug repertoire. For the first time, a prominent scholar Salman Mumtaz gave the information about Molla Juma and included his poems to the collection. The first example of Molla Juma's creations is found in Volume I of the book "Azerbaijani ashugs", published in 1929 by the renowned folklorist H. Alizadeh. This poem is his "deishme" with Khayyat Mirza. The poem is a mukhammas. In $1931 \mathrm{H}$. Alizadeh included 80 poems by Molla Juma in the book "Ashugs". Then the author of these lines was engaged in collecting poems, and published three books of the ashug in 1966, 1983 and 1995. Most of the poems have been collected in the latest edition. Molla Juma is also known for a few musicals: “"'gozallama” by Molla Juma”, "garayli by Molla Juma", "Sheki dubeyti", "mukhammas by Molla Juma". The latter is widespread in almost all Ashug regions.

It is known "deishme" between Molla Juma and ashug from Dagistan, Molla Juma and ashug Konul, Molla Juma and ashug Alasgar. In addition, in classical ashug poetry the recitation of all the letters of the Holy Quran was reflected in Molla Juma's creations. Molla Juma uses Arabic alphabet letters in a number of his poems. He uses these letters in such a way that they correspond to the rhymes of the poems, and he also uses certain words to convey some mysterious words. Molla Juma was the greatest thinker of his era. His creativity is based on the deep, mystical creation of this ancient art, and enriched it with his love of Oriental literature. Having benefited from sufism, by the effect of feelings of generosity, honesty, compassion the ashug conquered a great peak. In the nineteenth and twentieth centuries, innovations and classical ashug traditions developed in parallel in ashug creativity. First of all, the subjects they touched were already quite different from their predecessors. The themes of the 19th and 20th century ashugs were colorful. Real life facts, household issues, daily care and other such themes were brought to the poem and formulated the poetry of public ashug. But despite all this, lyricism is the core of Ashug's creativity. The beauty of man and nature, the inner world of man, the value given to the world, the moral values, religious and didactic themes were among the most frequently addressed poems.

Conclusion: In conclusion, it should be noted that ashug creativity is a national and spiritual wealth of the people, and it is a culture without analog. It has been at the forefront of our thinking, values, and identity for thousands of years. The medieval priests have passed through these traditions of art. The mood that ashug creativity instilled in us is the ancestor of our great-grandfathersn and it still holds the same sacred function today.

\section{References:}

1. Azərbaycan aşıqları (Toplayanı H.Đlizadə). Bakı, 1929.

2. Azərbaycan Mərkəzi Dövlət Tarix Arxivi. F. 10. S. 1. S.v. 101.

3. Azərbaycan Mərkəzi Dövlət Tarix Arxivi. F. 43. S. 2. S.v. 7183.

4. Azərbaycan Mərkəzi Dövlət Tarix Arxivi. F. 43. S. 2. S.v. 7385.

5. Aşılar (Toplayanı H.Olizadə). Bakı, 1931. II c.

6. Aşıqlar. Bakı, 1935.

7. Aşıqlar (Toplayanı H.Đlizadə). Bakı, 1937. 2-ci nəşri. I hissə.

8. Aşıqlar. Bakı, 1957.

9. El şairləri. Bakı, 1930.

10. Әfəndiyev P.Molla Cümə. Bakı, 2017.

11. Qasımzadə F. XIX əsr Azərbaycan ədəbiyyatı tarixi. Bakı, 1974.

12. Molla Cümə. Şeirlər. Bakı, 1966.

13. Molla Cümə. Әsərləri (Toplayanı, yazıya alanı və tərtib edəni prof.P.Әfəndiyev). Bakı, 1995.

14. Molla Cuma. Seçilmiş əsərləri. 3 cilddə, I cild (Toplayan, transliterasiya və tərtib edən, ön sözün, izahat, qeyd və şərhlərin müəllifi M. Yarəhmədov). Bakı, 2000.

15. Molla Cümə. Әsərləri (Tərtib edəni və ön sözün müəllifi P. Әfəndiyev). Bak1: 2006

16. Molla Cuma. İsmi Pünhan (Hazırlayanlar: M. Qasımlı, E. Әzizov). Bakı, 2016.

17. Namazov Q. Ozan-aşıq sənətinin tarixi. Bakı, 2013.

18. əbiyev A. Azərbaycan xalq ədəbiyyatı. 2 cilddə, II hissə. Bak1, 2014.

19. Paşayev S. XIX əsr Azərbaycan aşıq yaradıcıllı̆ı. Bakı, 1990.

20. Telli saz ustadları (Tərtib edəni Ә.Axundov). Bakı, 1964.

21. Yarəhmədov M. Molla Cuma. "Bakı" qəz., 25 aprel 1969.

Бабаєва М. Літературна спадщина Ашуга Молла Джуми та спосіб життя

Анотація. Творчість Ашуга - це національне і духовне багатство народу і це культура без аналогів. Він перебуває на передньому плані нашого мислення, цінностей та ідентичності вже тисячі років. Страждання середньовіччя передавали наші люди з цими традиціями мистецтва. Настрій, який прищепила нам творчість Ашуг, є предком наших прадідів, і він досі виконує ту саму сакральну функцію. У статті проаналізовано різні аспекти життя та творчості Молла Джуми - одного 3 неоціненних майстрів азербайджанського мистецтва ашуг. Зібрано та прокоментовано вірші майстра в різних джерелах, вірші на згадку про народних митців, розмови про нього. Висвітлено низку суперечливих моментів, а науково-теоретично проаналізовано спадщину М. Джуми. Мистецтво ашуг є невіддільною частиною нашої багатовікової історії та культури. 
Перлина мистецтва, яка наближає наше минуле до нашого сьогодення, а теперішнє - до нашого майбутнього, - це велике мистецтво, що уособлює побажання та прагнення людей. За цю рису ашуги відомі в народі як «ашуг істини», «голос ашуг - це голос правди» і «ашуг - краса народу». Один із них - Молла Джума - один із наймогутніших представників літератури ашуг, який жив і творив наприкінці XIX - початку XX століть. Краса людини і природи, внутрішній світ людини, цінність, що надається світу, моральні цінності, релігійні та дидактичні теми були одними 3 найчастотніших тем, яких він торкався у віршах. Молла Джума увійшов в історію літератури про ашуг як новаторський поет-ашуг. Його реконструкцію поезії Ашуг вітали як його сучасники, так і наступники. Основна частина поетичної спадщини великого художника досі зберігає його активність у репертуарі Ашуг. Уперше видатний учений Салман Мумтаз дав інформацію про Моллу Джуму та включив свої вірші до збірки. Перший приклад творчості Молли Джуми - це I книга книги «Азербайджанські ашуги», що вийшла в 1929 році за упорядкування відомого фольклориста X. Алізаде. «Дейшма» Молла Джума з Ашугом Конлу становить близько ста балів, і є багато барвистих тем. Особисті оригінальні думки ашугів про природу, суспільство, світ у цих «дейшме» зосереджені на питаннях високого таланту, духовного багатства, соціального, психологічного, етичного та виховання.

Ключові слова: музика, поема, національна, нація, творчість. 